\title{
Indonesian Economy-The Agriculture: kopi luwak
}

Shafitri Arindya Ramadhanty / 130418016

Faculty of Business and Economics, Universitas Surabaya

The increasing demand of kopi luwak began in 2003 when The Oprah Show featured it as "The Most Expensive Coffee in the World" and the movie "The Bucket List" made a bunch of reference to kopi luwak in 2007. The booming demand encouraged local farmers to establish The Association of Indonesian Coffee Luwak Farmers in 2009, with most of them being small businesses that have international market access (Pratono \& Radjamin, 2012). Despite the huge demand, kopi luwak only contributed around $0.0000437 \%$ (20-30 ton per annum) of the total Indonesian coffee production in 2018 (686,344 ton per annum-projection number) (PUSAT DATA DAN SISTEM INFORMASI PERTANIAN SEKRETARIAT JENDERAL KEMENTRIAN PERTANIAN, 2016) (GAEKI, 2018).

The Coffee Surplus Projection in Indonesia, 2016-2020

\begin{tabular}{|c|c|c|c|}
\hline \multirow[t]{2}{*}{ Year } & \multicolumn{2}{|c|}{ Projection (Tons) } & \multirow{2}{*}{$\begin{array}{c}\text { Surplus } \\
\text { (Tons) }\end{array}$} \\
\hline & Production & Consumption & \\
\hline $2016 *)$ & 667,655 & 302,176 & 365,479 \\
\hline $2017 * *)$ & 672,283 & 304,231 & 368,052 \\
\hline $2018 * *)$ & 696,344 & 306,183 & 380,161 \\
\hline $2019 * *)$ & 689,504 & 307,915 & 381,589 \\
\hline $2020 * *)$ & 692,906 & 309,771 & 383,136 \\
\hline \multicolumn{3}{|c|}{ Average } & 375,683 \\
\hline
\end{tabular}

Legend: *) Estimation

**) Projection Of Pusdatin 
World's Coffee Specialty

\begin{tabular}{|l|c|c|}
\hline \multicolumn{2}{|l|}{ A. Arabica (High Level World's Coffee Specialty) } \\
\hline 1. Aceh & Gayo Coffee & $30,000-40,000$ tons \\
\hline 2. North Sumatera & Mandheling Coffee & $10,000-15,000$ tons \\
\hline 3. North Sumatera & Linthong Coffee & $5,000-10,000$ tons \\
\hline 4. Bengkulu & Mangkuraja Coffee & $1,000-1,500$ tons \\
\hline 5. West Java & Java Preanger & $500-1,500$ tons \\
\hline 6. East Java & Java Coffee & $3,000-5,000$ tons \\
\hline 7. South Sulawesi & Toraja Coffee & $5,000-10,000$ tons \\
\hline 8. South Sulawesi & Toarco Toraja Estate Coffee & $500-1,000$ tons \\
\hline 9. South Sulawesi & Kali Kintamani Coffee & $5,000-10,000$ tons \\
\hline 10. Bali & God Mountain Coffee & $2,000-3,000$ tons \\
\hline 11. Bali & Flores Bajawa Coffee & $2,000-3,000$ tons \\
\hline 12. NTT & Baliem Valley Coffee & $500-1,000$ tons \\
\hline 13. Papua & Kopi Luwak & $20-30$ tons \\
\hline 14. Sumatera, Java, Bali, etc & Java Robusta WIB & $10,000-15,000$ tons \\
\hline B. Robusta Specialty $($ On Progress / Promotion) & $500-1,500$ tons \\
\hline 1. East Java & Bali Robusta WIB & $100,000-150,000$ tons \\
\hline 2. Bali & Linthong Coffee & $10,000-20,000$ tons \\
\hline 3. Lampung & Flores Robusta AP &
\end{tabular}

The low production capacity of kopi luwak indicates that kopi luwak represents a niche product (Pratono \& Radjamin, 2012), which is basically a concept of "Big fish in small pond" (Choudhary, 2014). Niche product focuses on a specialized consumer segment and limited market with few customers and competitors (Parrish, 2010) (Toften \& Hammervoll, 2009). For emerging economies, niche marketing is more suitable (Kotler, et al., 2009) and firms with niche products or services tend to be more aware of their customers (Luz, 2010) which enhances the competitive aspect of small firms.

While being a niche product has its advantage, kopi luwak also relies on resourcebased as a strategy. This strategy is a major theory in strategic management that emphasizes the resources of firm as the determinants of competitive advantage and performance (Bridoux, 2004) thus represents the Schumpeterian view of entrepreneurship that outlines how to seize opportunities within the potential utilization of resources or market imperfections (Hjorth \& Søren, 2011). A resource-based firm can gain a competitive advantage of its unique, valuable, non-substitutable to get more customer value (Liang, You, \& Liu, 2010) (Gerald, Janet, Kotabe, \& Lu, 2010). However, a common issue of resource-based taxonomy arises in these small to medium enterprises (Andersén, 2012). In the local market, the marketing of kopi luwak involves PT Rolas Nusantara 
Mandiri as an alliance strategy between PTPN XII and PTPN VIII. The establishment of several Rolaas cafes in Java and Bali contributed a significant sales growth of $\$ 10,000$ with the café located in Tunjungan being the highest contributor (Pratono \& Radjamin, 2012).

To complement niche marketing, PR strategy was implemented. PR itself is often associated with information flow management. Since advertising is quite ineffective due to an overwhelming number of advertisement, society finds PR strategy to be more relevant (Szondi, 2010). A negative perception from the media, however, becomes challenge PR practitioners have to deal with. Improving the relations with media is a must as media hostility is often hypocritical (Graeme, 2010). For PR practitioners in the future, organizational strategic position and communication competence will be a critical issue they need to address (Gregory, 2011).

Producing and marketing kopi luwak may be a good opportunity to penetrate global market; however, the production of kopi luwak itself reaped many controversy as People for the Ethical Treatment of Animals (PETA) published their investigation in 2013 and claimed that the making-process of kopi luwak reeks animal cruelty (Natahadibrata, 2013). BBC also made the same report after they did an undercover visit to some civet farms in northern part of Sumatra (Peresthu, 2013) which later triggered condemnation from wildlife activists over the cruel practice of kopi luwak production.

From this finding, PETA, that popularizes the motto "animals are not ours to eat, wear, experiment on, or use for entertainment" forced the Indonesian government to take an action over the mislabelling of 'wild' kopi luwak (Peresthu, 2013), which the government complied with the new law (PERATURAN MENTERI PERTANIAN REPUBLIK INDONESIA NOMOR 37/Permentan/KB.120/6/2015) regarding the production of kopi luwak that is cruel-free and focuses on the animal welfare.

The claim made by PETA, however, contradicted common sense as basically food like eggs, meats, fish, dairy products, and others are produced through animal cruelty (Peresthu, 2013). The accusation also pressured the producers, distributors, and expoters of kopi luwak in Indonesia as it made the international demand of kopi luwak kept declining. The demand in Europe and the U.S. was drastically decreased while the demand in Asian countries such as China, Japan, and Korea was still stable (Sucahyo, 2016). 
Still, the government and farmers work together to resolve the issue and try to make a better production system that is done under the name of conservation (Pratono \& Radjamin, 2012). 


\section{References}

Andersén, J. (2012). A resource-based taxonomy of manufacturing MSMEs. International Journal of Entrepreneurial Behaviour \& Research, 18(1), 98-122.

Bridoux, F. (2004). A RESOURCE-BASED APPROACH TO PERFORMANCE AND COMPETITION: An Overview of the Connections between Resources and Competition. Université catholique de Louvain, Belgium, Institut d'Administration et de Gestion.

Choudhary, S. (2014). Rooting By Niche Marketing. International Journal of Advanced Research in Management and Social Sciences, 3(10), 84-91. Retrieved from http://garph.co.uk/IJARMSS/Oct2014/7.pdf

GAEKI. (2018). Areal dan Produksi. Retrieved 2019, from Gabungan Eksportir Kopi Indonesia: https://gaeki.or.id/areal-dan-produksi/

Gerald, Y. G., Janet, Y. M., Kotabe, M., \& Lu, J. (2010). A 'strategy tripod' perspective on export behaviors: evidence from domestic and foreign firms based in an emerging economy. Journal of International Business Studies, 41(3), 377-396.

Graeme, D. S. (2010). Media perceptions of public relations in New Zealand. Journal of Communication Management, 14(1), 4-31.

Gregory, A. (2011). The state of the public relations profession in the UK. Corporate Communications, 16(2), 89-104.

Hjorth, D., \& Søren, H. J. (2011). Reading experience economy entrepreneurship cases using a resource based perspective. International Review of Entrepreneurship, 9(1), 3-23.

Kotler, P., Armstrong, G., Ang, S. H., Leong, S. M., Tan, C. T., \& Yau, O. M. (2009). Principles of Marketing: A Global Perspective. Englewood Cliffs, NJ: Pearson/Prentice-Hall.

Liang, T. -P., You, J. -J., \& Liu, C. -C. (2010). A resource-based perspective on information technology and firm performance: a meta analysis. Industrial Management + Data Systems, 110(8), 1138-1358.

Luz, T. S. (2010). Does niche marketing lead to business success? The case of M.C. Tamura. International Journal of Entrepreneurship, 14, 63-72.

Natahadibrata, N. (2013). PETA: Kopi Luwak reeks of animal abuse. Retrieved from The Jakarta Post: https://www.thejakartapost.com/news/2013/10/19/peta-kopi-luwak-reeks-animalabuse.html

Parrish, E. (2010). Retailers' use of niche marketing in product development. Journal of Fashion Marketing and Management, 14(4), 546-561. doi:https://doi.org/10.1108/13612021011081733

Peresthu, A. (2013). Luwak coffee: From animal welfare to national heritage. Retrieved from The Jakarta Post: https://www.thejakartapost.com/news/2013/10/31/luwak-coffee-fromanimal-welfare-national-heritage.html

Pratono, A. H., \& Radjamin, I. P. (2012). Kopy Luwak: a conservation strategy for global market. Emerald Emerging Markets Case Studies, 2(8), 1-5. doi:10.1108/20450621211294416 
PUSAT DATA DAN SISTEM INFORMASI PERTANIAN SEKRETARIAT JENDERAL KEMENTRIAN PERTANIAN. (2016). Outlook Kopi.

Sucahyo, N. (2016, June 15). Produsen Kopi Luwak Perbaiki Upaya Pemenuhan Hak Satwa. Retrieved from VOA Indonesia: https://www.voaindonesia.com/a/produsen-kopi-luwak-perbaikiupaya-pemenuhan-hak-satwa/3376806.html

Szondi, G. (2010). “From image management to relationship building: a public relations approach to nation branding. Place Branding and Public Diplomacy, 6(4), 333-343.

Toften, K., \& Hammervoll, T. (2009). Niche firms and marketing strategy. European Journal of Marketing, 43(11/12), 1378-1391. doi:https://doi.org/10.1108/03090560910989948 